\title{
Effectiveness of Training Program in Enhancing E-Assessment through Tablets and Smartphones: A Case Study of Saudi Arabia
}

\author{
Ahmed Maajoon Alanazi*, \\ Deanship of E-learning and Distance Education \\ Northern Border University, Arar, Kingdom of Saudi Arabia \\ Amalenezi@nbu.edu.sa
}

\begin{abstract}
*Corresponding author: Dean, Deanship of E-learning and Distance Education, Northern Border University, Arar, Kingdom of Saudi Arabia, Email: Amalenezi@nbu.edu.sa Contact Number: +966-502570134
\end{abstract}

\begin{abstract}
This research assess the effects of training program based on the usage of the digital learning objects in teaching practice at the Northern Borders University staff. E Assessment through the tablets and smart phones and the teachers' attitudes towards such way of evaluation is the major objective of this study as the researcher expects that the assessment mechanism in the university through utilization of tablets and smart phones and its application will inevitably bring in a systematic improvement in the assessment and evaluation process of the curricula. Moreover, making use of the e learning objects in training will make a significant change in e training program of the university.
\end{abstract}

Hence, the researcher has chosen voluntary random samples from the university teaching staff (men|women) from various different faculties (medicine, medical sciences, science, education and arts, business administration, home economics, and science and literature). These samples included 300 members of the teaching staff. In a group of 20 to 25 members, a personal training was conducted regarding the usage of tablets and smart phones and its applications in the assessment process. Each group participated by producing a complete e-assessment for their students in the Northern Borders University and by the e learning system i.e. Blackboard and Question Mark. The research also depends on the semi-experimental design of multiple groups and on testing the groups' pre and post achievement tests. In addition, the research identifies the level of the university teaching staff in using the tablets and the smartphones and its applications in the assessment process by the note card that the individuals have during the test.

\section{The keywords}

E Training- Digital Learning Objects- Electronic Assessment through the tablets and the smartphones and its applications. 


\title{
Effectiveness of training program in enhancing E-assessment through Tablets and Smartphones: A case study of Saudi Arabia
}

\begin{abstract}
This research assess the effects of training program based on the usage of the digital learning objects in teaching practice at the Northern Borders University staff. E Assessment through the tablets and smart phones and the teachers' attitudes towards such way of evaluation is the major objective of this study as the researcher expects that the assessment mechanism in the university through utilization of tablets and smart phones and its application will inevitably bring in a systematic improvement in the assessment and evaluation process of the curricula. Moreover, making use of the e learning objects in training will make a significant change in e training program of the university.
\end{abstract}

Hence, the researcher has chosen voluntary random samples from the university teaching staff (men $\backslash$ women) from various different faculties (medicine, medical sciences, science, education and arts, business administration, home economics, and science and literature). These samples included 300 members of the teaching staff. In a group of 20 to 25 members, a personal training was conducted regarding the usage of tablets and smart phones and its applications in the assessment process. Each group participated by producing a complete e-assessment for their students in the Northern Borders University and by the e learning system i.e. Blackboard and Question Mark. The research also depends on the semi-experimental design of multiple groups and on testing the groups' pre and post achievement tests. In addition, the research identifies the level of the university teaching staff in using the tablets and the smartphones and its applications in the assessment process by the note card that the individuals have during the test.

\section{The keywords}

E Training; Digital Learning Objects; Electronic Assessment; tablets; smartphones

\section{Introduction}

Boelens, van Wever, and Elen (2015) defined blended learning as "learning that happens in an instructional context which is characterized by a deliberate combination of online and classroombased interventions to instigate and support learning" (p.5). The online elements are not only 
used as supportive tools for effective classroom teaching; rather blended learning is supposed to be a perfect and effective integration of face-to-face and virtual methods (Garrison \& Kanuka, 2004). Studies by Lopez-perez, Perez-Lopez, and Rodriguez-Ariza (2011) and Boyle, Bradley, Chalk, Jones, and Pickard (2003) found that blended learning in higher education has improved retention and learners' attainment. It has significantly improved classroom attendance and learners' satisfaction as well which is eventually reflected in their performance in examinations. Moreover technology has improved the quality of classroom management wherein the teachers are empowered to make strategic use of technology in reinforcing learning undertaken in the classroom (Delialioglu, 2012). There is no dearth of evidences to support the benefit of blended learning in higher education but there is of course lack of awareness among the policy makers and the primary stakeholders like teachers who need to be exposed and educated to the benefits and implications of such technology which would enhance their teaching-learning experience. For a blended learning program to be successful it is necessary for the teachers to be properly trained and an ongoing evaluation should be conducted in order to assess proper implementation of such learning method (Garrison and Kanuka, 2004). Measuring learners' engagement, satisfaction, psychological investment in their learning, their active participation etc. would act as ongoing evaluation during the course of program to know the overall benefit of new method of learning.

E-learning framework (Khan, n.d.; Ozkan \& Koseler, 2009) identified various dimensions (pedagogical, technological, interface design, evaluation, management, resource support, ethical, and institutional) of its implementation. Among all the dimensions, evaluation is one of the prime elements which play an important role in the academic experience of teachers as well as the learners. A convenient, robust, simple, transparent method of evaluation gives clarity of achievement for the learners and the teachers. In a series of assessing the effectiveness of elearning in the academic set up of Northern Border University, various other project reports have been submitted to the university in order to identify all the issues comprehensively (Alenezi, 2017, 2016, 2015). In continuation to the effort, the present study deals with the acceptance of tablet and smart phones in the examination process and aims to assess if proper training programs are able to infuse excitement among the primary stakeholders. The Electronic Training is one of the most modern education ways and it actually imitates the development and the swiftness of the era where the modern technological communication tools such as computers, 
networks, and multimedia tools including sounds, images, cartoons, research mechanisms, electronic libraries, and electronic gates are used in face-to-face classes or distance mode of lectures. Using technology to deliver the information shortly and with the least effort is the code to success since the technology and information revolution has made the world as small as electronic screen where the technology, media, information, and culture have spread out substantially in the last two decades. Now, the electronic connection for information exchange among the computer networks is a tangible reality, which provides immense possibility of reaching out to the knowledge centers for science and libraries alike. It has enabled us to follow the news from across the globe second by second.

Mobile devices have become an integral part of our daily lives. It includes various electronic products such as, iPads, iPhones, iPods, etc. Worldwide sales of smart phones have reached 472 million in 2011, an increase of 58 percent over 2010 (Gartner Research, 2012). We don't need to memorize phone numbers now-a-days as we carry phone book in our pockets. Moreover we are connected to e-mail, text messaging, and information archive all the time which in turn has raised our dependency in all spheres of our lives. There is an equally competitive product which has attracted people's attention in the recent decade is tablets. A study proposed that by 2016 tablets will outsell desktop computers in the US (Forrester Research, 2014).

Global Internet Usage Stats (GIUS, 2017) suggests that there are 3.6 billion internet users across the globe and 21.5 percent of the users belong to middle-east. Mobile phones set to overtake PCs and Saudi Arabia has recorded 72.8 percent in terms smart phones adoption in Q1 2013. The record shows that smartphones and tablet cover 94.56 percent of global website traffic. Latest record shows that middle-east region which shares just 3.3 percent of world population (wherein Iran and Saudi Arabia has maximum users), has more internet penetration than the world average and even the rest of the world (Middle East Internet Usage and Population Statistics, 2017). Not only this mobile devices or tablets are used in physics theoretical classes as well as laboratories in order to enhance motivation level of the students (Kuhn \& Vogt, 2013,; Klein, 2014; Sans et al., 2017). These devices are found to be very useful and effective means of raising students' conceptual clarity as well (Gonzalez et al., 2015). Since the devices have become powerful tools for teaching, it has to replace the traditional methods as well as the teaching and testing should always go hand in hand in order to achieve the desired outcome. Hence, we can notice that there 
is a growing trend in terms of smart phone and tablets usage. The data supports that it is indisputable to apprehend its active role in educational institutions as well.

The electronic training based on the digital learning objects is one of the most prominent ways of electronic training that emerged in the latest decade of the current century. According to Loh, (2007), the electronic training based on the usage of digital learning objects increases the knowledge of the trainee, whereas the results of the study of Long, Bubois, \& Faley (2008) referred to the importance of using the digital learning objects in the electronic training in a bid to improve its outputs.

Similarly the study of Lorenzetti (2005) and Tannenbaum, \& Mathieu (2001) affirms that the electronic training in general and the electronic training based on the usage of the digital learning objects in particular increases the motivation of the trainer because such environment increases the trainer's independency and individuality. Besides this, it increases the possibility of the social networking with the trainees through the working groups that the trainer suggests in order to engage the trainees in a training environment.

Moreover, the electronic training based on the digital learning objects increases the chances of using the e-learning in the educational process, as the trainer has the entire experience from the beginning to the end. On this score, the study of Parrish (2004) found that the training of the university teaching staff on different programs especially that related to the electronic assessment increases the fields of the students' attainment in different university stages, which interprets the current trend of expanding the usage of the electronic assessment through the usage of the tablets and the smartphones, that will inevitably lead to the improvement of performance along with improvement of techniques in the assessment process. Clyde (2014) rightly expected that the number of e-learning users would be doubled during the coming years and would prove to be the flexible alternative for the traditional one.

There are a huge number of higher education institutions in the world in general and in the Saudi Arabia in particular which has been consistently striving to turn the traditional assessment process to electronic through the usage of the tablets and the smart phones. In this context, Wiley (2000) underlined the necessity of the training of university teaching staff in preparing and managing the electronic assessment process for the students in their respective programs of study 
in order to achieve the goal of comprehensive electronic learning and to reach the desired educational objectives from the entire learning process. In this directions, various recommendations have been made in order to implement technology in the educational process right from the knowledge dissemination to assessment and evaluation process (Informatics and the Competitiveness of the Open Education- Arab Republic of Egypt (2005); Twelve Scientific Conference of the Egyptian Assembly for the Educational Technology - Arab Republic of Egypt (2009); Twenty Conference of the Arab Union of the Libraries and Information - Lebanon (2010)). In today's world the learners are identified as digital natives who are born with technology exposure right from their early age. Moreover the teachers are identified as digital immigrants who interact with the so called traditional tools such as e-mails, electronic texts etc. (Thompson, 2013; Prensky, 2010). Many studies have stressed the importance of using the electronic assessment in the education programs due to its ability to assess and evaluate the knowledge the learner could attain. Furthermore, the $23^{\text {rd }}$ conference of the Arab Union for Libraries and Information - Qatar (2012) and the $3^{\text {rd }}$ International Conference on the Electronic and Distance Learning - Kingdom of Saudi Arabia (2013) underlined the necessity of integrating the modern technologies such as the smartphones and tablets and its applications in the electronic assessment process in higher education.

A major change has been marked in the way students interact with academic content, with teachers and peers, and the way they demonstrate their academic knowledge and skills, after the introduction of digital devices for instruction and assessment (Hamdon, Mcknight, McKnight, \& Arfstrom, 2013; Johnson, 2012; McCrea, 2011; Ballagas, Rohs, Shridan, \& Borchers, 2004). As per Speak Up 2013 survey of K-12 students, the most common use of devices include looking uo information on the internet ( $63 \%$ of the students), accessing online textbooks ( $43 \%$ of the students), communicating with peers and teachers ( $42 \%$ of the students) and taking online tests ( $40 \%$ of the students). Online testing has been so much diversified over in the recent times as it has moved beyond the traditional multiple-choice items in order to evaluate learners' competencies, achievements, or proficiency and so on. Instead 'technology-enhanced' item types (TEIs for short) that provides more authentic evaluation of the students' skills with reduced guessing and more use of constructed response. Diversity in technology in educational institutions also raise question whether all devices are equal when it comes to students take online test to demonstrate their skills. Professional testing standards (APA, 1986; AERA, APA, 
NCME, 2014, Standards, $9.7 \&$ 9.9) have stipulated that neither the delivery mode nor the devices should influence in any way the interpretations of assessment outcomes. This makes this study crucial as the teachers and learners need to show their comfort with these devices which would elicit fruitful results.

\section{Research problem:}

The Northern Borders University has been working consistently on developing the systems and methods of learning in the university under the supervision of the deanship of electronic and distance learning in a bid to guarantee the achievement of desired educational goals. Among the new integrated methods followed to develop the university educational process, electronic assessment as prepared by the deanship, is a platform for the electronic assessment through the use of tablets and smartphones. A system wherein the teaching staff members provides a questions bank that produces electronic tests is allocated only for the students, though it received a weak response from the teachers as well as the students. There was still some resistance from some teaching staff members against the electronic assessment system based on the usage of the tablets and the smartphones. Thus, the deanship decided to train the teaching staff but the training couldn't help in achieving the expected results due to the lack of the applications and devices the students can use. It was also noticed how the trainees reacted differently towards the training process.

Unregulated interviews with some teaching staff members who have negative attitudes towards the electronic assessment, revealed their needs to untraditional training programs that may help them in gaining the electronic assessment skills. The deanship actually tried to provide the applications and techniques used to coach the teaching staff by the traditional ways, but the technological systems and information security systems relevant to the electronic assessment in the university didn't support such traditional way. Although some of the teaching staff members have their tablets and smartphones, the devices used by the students are supported by specific systems diverse from one to another. Moreover the teacher can't use such systems in traditional way so they asserted their need for untraditional training system depending on the electronic training while taking into account the individual disparities and such virtue is actually provided by the electronic training based on the digital learning objects. The digital learning objects can help the trainee in experiencing a synchronized and an unsynchronized modes of training via 
images, visible and audible scenes etc., keeping in mind the self-learning pace of each trainee, which eventually helps in reaching the desired effect of the electronic assessment process of students (Wiley, 2000; Parrish, 2004; Clyde, 2014).

Therefore, the present study aims to assess the skill sets required by the teaching staff of Northern Border University to operate the electronic assessment based on the tablets and the smart phones. It also aims to explore the negative attitude of some teaching staff members towards this proposed system and the reasons for their resistance against the implication of such assessment tool, despite the university provision of such technologies and some relevant devices.

\subsection{Research questions}

The current research aims to address the following:

How an electronic training program based on the digital learning objects can help the teaching staff at Northern Borders University in their acquisition of the skills needed for the electronic assessment through tablets and smart phones and its applications and how can it affect their attitudes towards the new system? This major question implies other two sub questions as below:

a. What are the training needs of the teaching staff to use the electronic assessment through the tablets and smart phones and its applications?

b. What is the nature of the training program based on the digital learning objects that aims at helping the teaching staff members in the acquisition of the skills necessary in the electronic assessment through the tablets and smart phones?

c. What are the skill-sets required by the teaching staff members to use the electronic assessment through the tablets and the smartphones and its application in the educational process?

d. How does the program affect the attitude of the teaching staff members to think positively about the usage of the electronic assessment through the tablets and the smart phones?

\subsection{Importance of this research}

The significance of this research prevails in the acquisition of the electronic assessment through the tablets and smart phones and its applications by the various stakeholders in general and teaching staff in particular at the Northern Border University, KSA. Further this research will 
strive to infuse positive attitude towards that new method of assessment in the educational process among the major stakeholders.

\subsection{Research objectives}

a. Identification of the appropriate training needs of the Northern University teaching staff in order to acquire the desired skills of the electronic assessment via the tablets and the smartphones and to improve their attitude towards such technique.

b. Recognition of the most important skills as required by the university teaching staff to conduct the assessment through the tablets and the smartphones.

c. Assessment of the attitudes of the university teaching staff towards the assessment process through the tablets and the smartphones.

d. Assessment of the nature of a proposal for training program that is based on the use of digital learning objects which help the teaching staff to acquire the skills of the electronic assessment through the tablets and the smart phones and which eventually to improve their attitudes towards the new way of assessment.

e. Assessment of the change in their attitude towards e-assessment after going through the training program.

\subsection{Research hypothesis}

The following hypotheses have been formed in the proposed study:

a. There is no statistically significant difference with the level $>(0.05)$ among the average score of the experimental group members in terms of the knowledge realization owing to the proposed training program.

b. There is no statistically significant difference with the level $>(0.05)$ among the average score of the experimental group members in terms of the skills required of the electronic assessment that is based on the tablets and the smart phones due to the proposed training program.

c. There is no statistically significant difference with the level $>(0.05)$ among the average score of the experimental group members in terms of the attitude towards the usage of the electronic assessment that is based on the tablets and the smartphones in the educational process as a result of the proposed training program.

\section{Research Methodology}


Experimental approach: The researcher uses the developmental searching approach by applying the Gazar sample (2013) of the educational development for developing the training program to train the university teaching staff on the usage of the tablets and the smartphones and its applications in the electronic assessment process and to improve their attitude towards it.

The research sample randomly consists of (300) members of the Northern Borders University teaching staff, as the sample is divided randomly into number of groups study according to their search and design variables.

\subsection{The experimental design}

This research includes the variables as listed below:

a. The independent variable: the training program that is based on the digital learning objects.

b. The dependent variables:

The dependent variable includes: the knowledge aspects, the skill aspects, and the university teaching staff attitudes towards the electronic assessment based on the tablets and the smartphones.

\begin{tabular}{|c|c|c|}
\hline $\begin{array}{l}\text { Pre-assessment } \\
\text { Requirements }\end{array}$ & Experimental Treatment & $\begin{array}{l}\text { Post -assessment } \\
\text { Requirements }\end{array}$ \\
\hline $\begin{array}{l}\text { Testing the knowledge aspects } \\
\text { Measuring the attitudes } \\
\text { Note card }\end{array}$ & $\begin{array}{l}\text { Applying the training } \\
\text { program based on the } \\
\text { digital learning objects on } \\
\text { the various experimental } \\
\text { groups }\end{array}$ & $\begin{array}{l}\text {-Testing the knowledge aspects } \\
\text {-Measuring the attitudes } \\
\text {-Note card }\end{array}$ \\
\hline
\end{tabular}

Table 1. Experimental design of the research

The current research depended on the experimental design of multi experimental groups with the multi group Pre Test and Post Test, as the sample individuals were chosen randomly and then divided into multiple groups. The pre measurement tools are applied on the groups before the experiment, then, the experimental groups are trained through the training program that is based on the digital learning objects to teach them the electronic assessment through the tablets and the smartphones and its applications. After the experiment, the measurement tools are applied on the 
experimental groups to mark the changes in order the impact of the training programs so as to meet the expected results.

\subsection{Tools \& Instruments}

The following tools were used in the present research:

a. Acheivement test. (Prepared by the researcher)

b. Attitude measurement scale towards the usage of the electronic assessment. (Prepared by the researcher)

c. Note card. ((Prepared by the researcher)

\section{Research results:}

\subsection{Applying a card of evaluating the training needs:}

Training needs evaluation card is conducted on three hundred teaching staff members (menlwomen) from across the faculties of the Northern Border University (medicine, medical science- science- education and literature- business administration- home economics- sciences and literature). The samples were divided into seven groups (each one comprised of 20-25 members). Distribution of the faculties in each group is as follows (table 2):

\begin{tabular}{c|c|c|l}
\hline Faculty & \multicolumn{2}{|c|}{ Genre } & Total \\
\hline Medicine & Men & 18 & 38 \\
\hline Medical sciences & 20 & 20 & 43 \\
\hline Sciences & 23 & 20 & 44 \\
\hline Education and \\
literature & 24 & 25 & 50 \\
\hline Business administration & 25 & 25 & 50 \\
\hline Home economics & 25 & 25 & 50 \\
\hline Sciences and literature & 0 & 35 & 50 \\
\hline Total & 25 & 158 & 300 \\
\hline
\end{tabular}

\section{Table 2: Organization of research sample}

The second step is processing of the training needs evaluation card related to skill-sets needed for the electronic assessment via the tablets and the smart phones and its applications. The table below as shown in the table below (3) 


\begin{tabular}{l|l|l}
\hline Subject & Subsidiary skills & Needs percentage \\
\hline $\begin{array}{l}\text { First: the concepts related to the } \\
\text { tablets and the smartphones and } \\
\text { its applications }\end{array}$ & 10 & $96 \%$ \\
\hline Second: cognitive aspects & 18 & \\
\hline Third: skill aspects & 16 & $98 \%$ \\
\hline
\end{tabular}

After the above procedures, the skills under the training program could be identified and so as the corresponding performance of the searching samples on the desired skill-sets.

A. Setting of the attainment test: The questions included in the attainment test have been identified as below in table (4)

\begin{tabular}{c|c|c|c|c|c|c|c|c|c|c}
\hline Levels & \multicolumn{2}{|l|}{$\begin{array}{l}\text { Memory/Understanding/ } \\
\text { Application/Misc. }\end{array}$} & $\begin{array}{c}\text { Topic } \\
\text { objectives }\end{array}$ & $\begin{array}{c}\text { Question- } \\
\text { sets related } \\
\text { to the topic }\end{array}$ & $\begin{array}{c}\text { Percentage } \\
\text { of objectives }\end{array}$ & $\begin{array}{c}\text { Percentage } \\
\text { of questions }\end{array}$ \\
\hline & 6 & 6 & 8 & 8 & 10 & 10 & 24 & 24 & $38.88 \%$ & $42.45 \%$ \\
\hline
\end{tabular}

Table 4: Designing the attainment test

Then, the researcher has counted the internal consistency coefficient of the attainment test (Cronbach's a. $\alpha$ ) by using the program of (SPSS) on the post test scores as stated in the table 5 below.

\begin{tabular}{l|l|l|l}
\hline Value & Objects of the test & Total Samples & Internal consistency coefficient \\
\hline 0.976 & 24 & 300 & Cronbach's $\alpha$ \\
\hline
\end{tabular}

Table 5: Internal consistency coefficient of the test

According to the table above, it can be noticed that the consistency coefficient of the attainment test (0.976) refers to the accuracy of the measurement test (capabilities and its credibility) in terms of the cognitive or knowledge aspect of the research samples.

After this procedure, the researcher estimated the consistency of the note card in terms of the performance of skills as required of the electronic assessment through the tablets and the 
smartphones and its applications by the consistency coefficient Cornbach (a- $\alpha$ ) and (SPSS) program on the post application grades as shown below in table 6:

\begin{tabular}{l|l|l|l}
\hline Coefficient Cornbach $\alpha$ & Total samples & The note card contents & Value \\
\hline Cornbach $\alpha$ & 300 & 24 & 0.948 \\
\hline
\end{tabular}

Table 6: Internal consistency of the note card

In the table above, it can be noticed that there is an increase in the consistency coefficient of the note card in terms of the performance of skills (0.948) which refers to the accuracy of the card in measuring the information provided about the level of the individuals' performance (members of the Northern Borders University teaching staff)

Statistical operations for the tools and estimation of the results: Calculation of average and the standard deviation of the sample individuals' grades $(\mathrm{N}=300)$ in pre and post application and general achievement percentage of the training program as shown in table 7 below.

\begin{tabular}{l|l|l|l|l}
\hline $\mathrm{O}$ & Tool & Measurement & Average & The standard deviation \\
\hline 1 & Achievement test & Pre & 10 & 11.135 \\
\cline { 3 - 5 } & Post & 23 & 11.196 \\
\hline 2 & Note card & Post & 62 & 13.840 \\
\hline 3 & $\begin{array}{l}\text { Percentage of general } \\
\text { achievement }\end{array}$ & 109 & 9.653 \\
\hline
\end{tabular}

Table 7. General achievement percentage of the training program

As for the table above, all individuals of the sample group have scored higher than $90 \%$ in the achievement test, as the average estimation of the post test (23 or 24) is higher than $90 \%$. Moreover, all experimental group members scored an average of higher than $80 \%$ in the performance of note- card skill. The average estimation of general achievement (109) after the training program refer to the efficiency of the training program in improving skills of the electronic assessment via the tablets and the smart phones.

(1) Testing the first hypothesis: The researcher applied the (T) test on the independent samples to know the significance of the difference between the average score of the 
experimental group in achievement test after undergoing the training program. (SPSS) program was used for this study. It is shown in table 8 below:

\begin{tabular}{|c|c|c|c|c|c|c|}
\hline $\mathbf{N}$ & Average & $\begin{array}{c}\text { Standard } \\
\text { Deviation }\end{array}$ & T value & $\begin{array}{c}\text { Degree of } \\
\text { Freedom }\end{array}$ & $\begin{array}{c}\text { Significance } \\
\text { Value }\end{array}$ & $\begin{array}{c}\text { Significance } \\
\text { Level }\end{array}$ \\
\hline 300 & 23 & 12.66 & 2.645 & 27 & 0.044 & 0.05 \\
\hline
\end{tabular}

Table 8: T-test for post-achievement test

According to the table 8 , the average grade of the experimental group in achievement test is increased to 23 which is way more that the pre-program score. The T-test value estimated in the achievement test was 2.645 with degree of freedom 27 whereas their computerized estimated indication was 0.044 . Since the level of significance is less than 0.05 , the first hypothesis is refused as hypothesis stated that there was no significant statistical difference with the level $>$ (0.05) among the average grades of the experimental groups.

(2) Testing the second hypothesis: The researcher applied the T-test on the independent samples (SPSS program) to know the significance of the difference among the average achievement of the experimental group in the post note-card activity that monitors the skill of producing the electronic curriculums through the web, as shown in the table 9:

\begin{tabular}{l|l|l|l|l|l|l}
\hline $\mathbf{N}$ & Average & $\begin{array}{l}\text { Standard } \\
\text { Deviation }\end{array}$ & T value & $\begin{array}{l}\text { Degree of } \\
\text { Freedom }\end{array}$ & $\begin{array}{l}\text { Significance } \\
\text { Value }\end{array}$ & $\begin{array}{l}\text { Significance } \\
\text { Level }\end{array}$ \\
\hline 300 & 109 & 15.37 & 2.61 & 27.54 & 0.015 & 0.05 \\
\hline
\end{tabular}

Table number (9) T Test on the posteriori notes test

According to table 9, the average of the experimental group individuals' has increased significantly (109) in terms of the note-card related to monitoring the skill of using tablets and smart phones. The $\mathrm{T}$ value estimated in the card was 2.61 with degree of freedom 27.54 and its computerized estimated significance was 0.015 . Since this significance was less than 0.05 , the $\mathrm{T}$ value is considered to favor the teaching staff skills of using the tablets and the smart phones. Thus, the second hypothesis is proved to be wrong which states that there is no statistically significant difference in the level $>(0.05)$ among the 
average of the experimental group individuals' skill of using electronic assessment based on tablets and smart phones.

(3) Testing the third hypothesis: The researcher analyzed the disparity of the post training program scores to measure the attitude of the Northern Borders University teaching staff towards the electronic assessment via the tablets and the smart phones, as is shown in the table 10:

\begin{tabular}{|c|c|c|c|c|c|c|}
\hline \multirow{2}{*}{$\begin{array}{c}\begin{array}{c}\text { Disparity } \\
\text { source }\end{array} \\
\text { Attitude }\end{array}$} & \multicolumn{2}{|c|}{ Total Squares } & \multirow{3}{*}{$\begin{array}{c}\begin{array}{c}\text { Degree of } \\
\text { Freedom }\end{array} \\
1\end{array}$} & \multirow{3}{*}{$\begin{array}{c}\begin{array}{c}\text { Groups' } \\
\text { Averages }\end{array} \\
1920.06\end{array}$} & \multirow{2}{*}{$\begin{array}{c}\begin{array}{c}\text { A } \\
\text { percentage }\end{array} \\
937.41\end{array}$} & \multirow{2}{*}{$\begin{array}{c}\begin{array}{c}\text { Level of } \\
\text { Significance }\end{array} \\
0.01\end{array}$} \\
\hline & Among & 1786.43 & & & & \\
\hline towards the & groups & & & & & \\
\hline \multirow{2}{*}{$\begin{array}{l}\text { usage of the } \\
\text { electronic }\end{array}$} & Total & 1954.81 & 104 & -- & & \\
\hline & Inside & 178.38 & 106 & 1.784 & & \\
\hline assessment & groups & & & & & \\
\hline $\begin{array}{l}\text { via the tablets } \\
\text { and the } \\
\text { smartphones }\end{array}$ & Total & 2545.46 & 103 & -- & & \\
\hline
\end{tabular}

Table 10. Post training program scores measuring the attitude of teaching staff towards electronic assessment

In table 10 above, the A percentage among the grades of the sample group appears significant at the level 0.01 in developing the attitude of teaching staff in the Northern Borders University towards the usage of the electronic assessment through the tablets and the smartphones with an A percentage 937.41. Since the results of analyzing the disparity refers to an A percentage statistically significant at the level 0.01, the researcher felt the need of using the Scheffe test to compare the averages of scores among the groups in order to measure the attitudes of the Northern Borders University staff towards the usage of the electronic assessment through the tablets and the smartphones and the table 11 below shows interesting results.

\begin{tabular}{l|l|l}
\hline Total comparisons & Averages & Level of Significance \\
\hline $\begin{array}{l}\text { The attitude of the Northern } \\
\text { Borders University teaching }\end{array}$ & 113.11 & 0.01 (high significance) \\
\hline
\end{tabular}




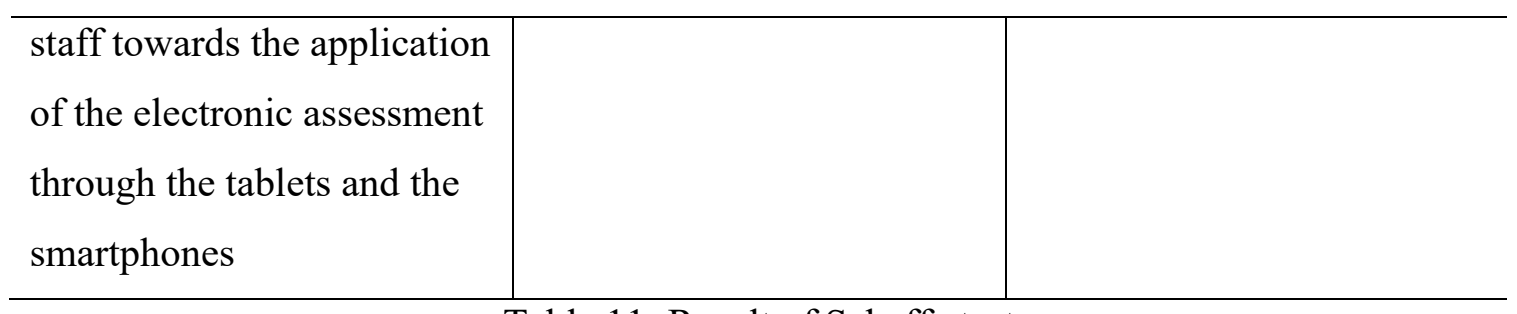

Table 11: Result of Scheffe test

Extrapolating the table 11 results, statistically significant differences can be noticed in addition to high of positive attitude towards the usage of the electronic assessment via smart phones and tablets. Thus, the third hypothesis was proved to be wrong as well. This third hypothesis stated that: there was no statistically significant difference with the level $>(0.05)$ among the average score of the experimental group members in terms of the attitude towards the usage of the electronic assessment based on tablets and smart phones.

\section{Discussion and Implication}

The study presents interesting results into ongoing practices of using technology in education. In KSA. It will serve as a stepping stone in turning the mode of knowledge dissemination and restructure the evaluation and assessment procedures. It is not only going to improve learners' motivation but also enhance transparency in the assessment process. The findings in the present study are in line with the other studies wherein the use of computer plays a significant role in educational process (Bangert-Drowns et al., 1985; Lungberg, 1995; Marzban, 2011; Sotoudehnama, 2014; Leis et al., 2015). Computer based learning not only increases learners' motivation level but also provide them with immediate feedback on their learning trends (Soe, 2000). Later Leis (2015) also claimed that learners encouraged using smartphones during their regular scheduled classes are found to be more inclined towards using them in their free time and also showed signs autonomy over their learning process. Nevertheless there are scholars who argue against these findings and claim that there is a lack of human emotions when too much of technology is involved in the learning process (Gulley, 2003).

In Iran, the EFL learners showed more positive attitudes towards the use of tablets than the smart phones (Ansarin et al., 2017). Studies conducted in the areas of ESL and EFL proved that learners are more inclined towards tablets over the smart phones and desktops because of their larger size and efficiency (Forrester research, 2010). It has been observed that desktops are more 
prone to technical snags which prevent the learners from fruitful educational experience. Since Northern Border University is presently in its initial stage of technology intervention in the teaching-learning process. Identifying the training needs of the teaching staff members to use the tablets and the smartphones in the electronic assessment of the students in the Northern Borders University was the major one of the objectives of the training program. Blended learning has become very popular in higher educational institutions in recent times. Such experience can be applied in all the kingdom's universities. It is the primary goal to identify the most important skills that should be available with the university teaching staff to make advantage of the tablets and the smartphones and its applications in the electronic assessment for students.

A training program related to using the digital learning objects to help the university teaching staff in using the tablets and the smartphones and its applications in the electronic assessment is conducted in order to develop a positive attitude with the university teaching staff towards the usage of the tablets and the smartphones in the electronic assessment of the students. It will eventually improve the assessment process in the university through providing the teaching staff members with the skills necessary for the electronic assessment of the students. The research introduces a result that can be useful for those working on preparing electronic training program based on the digital learning objects and can stand as a guide on the procedural level to develop a training program. It opens various dimensions for researchers to prepare studies and researches in the field of designing electronic assessments based on the tablets and the smartphones and its applications.

Various studies have suggested that there is no difference in the performance scores of the students in terms of the devices used for testing and evaluation (Davis, Orr, Kong, and Lin, 2015; Olsen, 2014). It has also been observed that use of tablets has moved forward in many assessment programs (PARCC, 2015). The results of the present study should not be interpreted that tablet is the only appropriate tool to be used for assessment purpose. The other devices are equally applicable and should be used where the resources are limited and infrastructural issue dominates the other core areas. 
University budgetary provision is allocated in order to raise the teaching and learning experience through using the resources available for teaching and making use of it in developing the educational process. This will in due course raise the university status in terms of modernization, use of latest methods and technology use in educational programs delivery and assessment procedures.

\section{Conclusion \& Recommendations:}

The training program on different educational levels is found to be very effective in universities of the Kingdom of Saudi Arabia. The suggested training program is found to be effective in improving students' attainment in their various educational programs. Motivating the teaching staff members to use the electronic assessment based on the tablets and the smartphones and its application in their curriculums is one of the necessary factors to be implemented for the success of e-learning program. In the context of Saudi Arabia, perceived barriers towards e-learning are gender specific, as female faculty members are found to have less e-learning barriers than their male counterparts (Ghamdi et al., 2017). Though the government has been spending huge grants for the universities to fully implement e-learning and technology in education, a strategic planning is needed to successfully achieve the desired objectives. This will subsequently improve upon the pedagogical barriers and this study proposes that proper training programs would ensure successful implementation in assessment and evaluation procedures. Of course there are ethical issues and as there are studies that have reported that the gadgets have generated a new form of cheating and the universities are struggling to make the system robust and more reliable (Brian, 2016). But it's quite unquestionable to overlook the impact of technology in various dimensions of knowledge dissemination. What is more needed is just more advancement to enhance the reliability and validity of such procedures.

\section{References}

Brian E. M. 2016. What do first-year engineers and others consider cheating?. Frontiers in Education Conference (FIE) 2016 IEEE, 1-6.

Ghamdi, M. A., \& Samarji, A. 2016. Perceived Barriers towards e-Learning by Faculty Members at a Recently Established University in Saudi Arabia. International Journal of Information and Education Technology, 6 (1), 23-28. 
Alenezi, A. M. 2012. Faculty memberse perception of e-learning in higher education in the Kingdom of Saudi Arabia (KSA). Texas Tech University, USA.

Alwani, A. E. S., \& Soomro, S. 2010.Barriers to effective use of information technology in science education at Yanbu Kingdom of Saudi Arabia. InTech 6 (2). 24-29.

MOHE. 2011. About the National Centre of e-Learning \& Distance Learning in Saudi Arabia. [Online]. Available: http://www.mohe.gov.sa/ar/Ministry/Deputy-Ministry-for-Planning-a ndInformation-affairs/Pages/edition.aspx

Ballagas, R., Rohs, M., Sheridan, J. \& Borchers, J. 2004. BOYD: bring Your Own Device. UbiComp 2004 Workshop on Ubiquitous Display Environments, September, Nottingham, UK.

Amrecan Educational research Association (AERA), American Psychological Association (APA), and the National Council on Measurement in Education (NCME). 2014. Standards for educational and psychological testing. Washington, DC.

Davis, L. L., Orr, A., Kong, X., \& Lin, C. 2017. Assessing students writing on tablets. Educational Assessment. Vol 24 (4).511-515.

Kingston, N. M. 2009. Comparability of computer and paper administered multiple choice tests for K-12 populations: A synthesis. Applied Measurement in Education, 22 (1), 22-37.

Olsen, J.B. 2014. Score comparability for web and ipad delivered adaptive tests. Paper presented at the Annual Meeting of the national Council on Measurement in Education, Philadelphia, PA.

Forrester Research. 2010. Available on:

https://www.forrester.com/report/Forrester+Research...2010+to.../-/E-RES58079

Partnership for the assessment of Readiness for college and Careers. 2013. Technology Guidelines for PARCC assessments version 2.1. Retrieved from http://www.parcconline.org/sites/parcc/files/PARCCTechnologyGuidelines2dot1_Feb2013Updat e.pdf

Gonzalez, M. A., Gonzalez M. A., Martin M.E., Llamas, C., Martinez, O., Vegas, J., Herguedes, M., \& Hernandez, C. 2015. Teachng and Learning Physics with Smartphones. Journal of Cases on Information technology, 17 (1). 112-148. 
Kelin, P., Hirth, M., Grober, S., Kuhn, J., \& Muller, A. 2014. Classical experiments revisited: smartphones and tablets PCs as experimental tools in acoustic and optics. Physics Education, 49 (4). 412-418.

Kuhn, J., \& Vogt, P. 2013a. Smartphones as experimental tools: Different methods to determine the gravitational acceleration in classroom physics by using everyday devices. European Journal of Physics Education, 4(1), 16- 27.

Kuhn, J., \& Vogt, P. 2013b. Applications and Examples of Experiments with Mobile Phones and Smartphones in Physics Lessons. Frontiers in Sensors, 1(4), 67-73.

Sans, J. A., Gea-Pinal, J., Gimenez, M. H., Esteve, A. R., Solbes, J., \& Monsoriu, J. A. 2017. Determining the efficiency of optical sources using a smartphone's ambient light sensor. European Journal of Physics, 38(2), 025301.

Boyle, T., Bradley, C., Chalk, P., Jones, R., \& Pickard, P. 2003. Using blended learning to improve student success rates in learning to program. Journal of Educational Media, 28 (2-3). 165-178.

Garrison, D. R., \& Kanuka, H. 2004. Blended learning: Uncovering its transformation potential in higher education. The Internet and Higher Education, 7 (2). 95-105.

Delialioglu, O. 2012. Student engagement in Blended Learning Environments with LectureBased and Problem-based Instructional Approaches. Journal of Educational Technology \& Society, 15 (3). 310-322.

Khan, B. (n.d.). E-learning Framework and Models. Retrieved on $14^{\text {th }}$ April 2016 from http://asianvu.com/bk/framework/

Krause, K.L., \& Coates, H. 2008. Students'engagement in first year university. Assessment \& Evaluation in Higher Education, 33 (5). 493-505. Retrieved from http://www.tandfonline.com/doi/abs/10.1080/02602930701698892

Ozkan, S., \& Koseler, R. 2009. Multi-dimensional students' evaluation of e-learning systems in the higher education context: An empirical investigation. Computers \& Education, 53 (4). 12851296.

Gartner Research. 2012. Available on: https://www.gartner.com/newsroom/id/2124315 
Sotoudehnama, E., \& Dehghan, H. 2013. The effect of call software on Iranian EFL learners' reading comprehension. Iranian Journal of Language Issues, 1 (1). 25-30.

Leis, A., Tohei, A., \& Cooke, S. 2015. Smartphone assisted language learning and autonomy. International Journal of Computer Assisted Language Learning and Teaching, 5 (3). 75-88.

Marzban, A. 2011. Improvement of reading comprehension through computer assisted language learning in Iranian intermediate EFL students. Procedia Computer Science, 3. 3-10.

Wei, F. Y.F., Wang, Y. K., \& Klausner, M. 2012. Rethinking college students' self regulation and sustained attention: Does text messaging during class influence cognitive learning? Communication Education, 61, 185204.

Internet World Stats. 2015. Usage and Population Statistics [Data file]. Internet usage in the Middle East. Retrieved from http://www.internetworldstats.com/me/ir/htm

Couper, M. P., Tourangeau, R., \& Conrad, F. 2004. What they see is what we get response options for web surveys. Social Science Computer Review, 22. 111-127.

Clyde, L. A. 2004. Digital learning objects. Teacher Librarian, 31(4), 55-58 .

Loh, B. H. 2007. The Antecedents and Outcomes of E-Learning Effectiveness in the Manufacturing Industry (Unpublished master's thesis). School of Management, University Sains Malaysia, Penang.

Hamdan, N., McKnight, P., McKnight, K., \& Arfstrom, K. M. 2013. A Review of Flipped Learning. Available on: http://www.flippedlearning.org/review

Long, L. K., DuBois, C. Z., \& Faley, R. H. 2008. Online training: The value of capturing trainee reactions. Journal of Workplace Learning, 20 (1), 21-37.

Lorenzetti, J. P. 2005. How e-learning is changing higher education: A new look. Distance Education Report, 22, 4-7.

Parrish, P. E. 2004. The trouble with learning objects. Educational Technology, Research and Development, 52 (1), 49-68 .

Tracey, J. B., Hinkin, T. R.,Tannenbaum, S., \& Mathieu, J. E. 2001. The influence of individual characteristics and the work environment on varying levels of training outcomes. Human Resources Development Quarterly, 12 (1), 5-23. 
Wiley, D. A. 2000. Connecting learning objects to instructional design theory: A definition, a metaphor, and a taxonomy. In D. A. Wiley (Ed.), The instructional use of learning objects: Online version. Retrieved from http://wileyDA/pdf

Wang, M., Shen, R., Novak, D., \& Pan, X. 2009. The impact of mobile learning on students' learning behaviours and performance: report from a large blended classroom. British Journal of Educational Technology, 40 (4). 673-695.

Unesco. Unesco ICT Competency framework for teacher, 7-12, http:// unescodoc.unesco.org/images/0021/002134/213475e.pdf, downloaded June $17^{\text {th }} 2015$.

Ahmed, H. M. S. 2010. Hybrid e-learning acceptance model: Learner perceptions. Decision Sciences Journal of Innovative Education, 8 (2), 313 - 346.

Alenezi, Ahmed. 2017. Checking on Preferential Choices of E-learning \& M-learning: A Case Study of Northern Border University, Saudi Arabia. International Journal of Emerging Technologies in Learning (iJET), 12 (5). 98 - 116

Alenezi, Ahmed. 2017. Implementation of Smartphones, Tablets and their Applications in the Educational Process Management at Northern Border University. International Journal of Educational Sciences. 18 (1-3). 56 - 64. 